\title{
Most Easy on the Pocket Offloading Device Costing $<1 \$$ for Rural Diabetic Foot Ulcers
}

\section{Vijay P Agrawal* and P N Sreeramulu}

Department of General Surgery, Sri Devraj Urs Medical College, Tamaka, Kolar, Karnataka, India

\begin{abstract}
Objectives: The aim of our study is to compare mandakini offloading device suitable for low socio-economic rural population with conventional dressing in the treatment of diabetic foot plantar ulcers.

Methods: From December 2010 to June 2012, 80 patients with diabetic plantar neuropathic ulcer were randomised to Mandakini offloading device $(n=40)$ or Conventional dressing $(n=40)$.

Results: No significant differences between the two groups with respect to baseline ulcer size (4.52 vs $4.67 \mathrm{cms})$. The Number of patients with no necrotic tissue is significantly higher in Test group at $6^{\text {th }}$ week follow up (32 vs 8 ). The number of patients with $75-100 \%$ wound filled by granulation tissue is significantly higher in test group at $6^{\text {th }}$ week follow up (32 vs 8). The number of patients with no wound surface (Healed ulcer) is significantly higher in test group at $6^{\text {th }}$ week follow up (32 vs 10). P value less than 0.001 was the level of significance.
\end{abstract}

Conclusion: Mandakini offloading device is economical, effective and feasible for rural population.

Keywords: Offloading; Diabetic plantar ulcers; Mandakini offloading device

\section{Key Points}

The study was done to give an insight to the depth of diabetic wound management, as it has become a foremost problem in recent era. Offloading is one of the cornerstones of gold-standard treatment in diabetic neuropathic foot ulcer. The study shows the fine efficacy of mandakini offloading device in terms of duration of healing of ulcer, no infection and no recurrence. It is economical, effective and easy to apply.

\section{Introduction}

India has the largest number of people with diabetes in the world. Today Indian Diabetic population is about 61.3 millions [1] that means total 122 million foot is at risk of getting Diabetic Foot Ulcer (DFU). It is also expected that this figure in 2025 will reach to 73.5 million [2]. Every $3 \mathrm{sec}$ a new case of diabetes is diagnosed and every $30 \mathrm{sec}$ a lower limb is amputated somewhere due to diabetes [3]. Worldwide, more than 1 million amputations are performed each year with up to $70 \%$ of these amputations related to diabetes. Foot problems are common, complex, and costly problem in a patient with diabetes [4-7]. It is a commonest cause of hospital admissions for people with diabetes [8]. It is estimated that $15 \%$ of patients with diabetes will develop a lower extremity ulcer during the course of their disease [9]. Diabetic patients are 17 times more likely to develop gangrene of the foot than are persons without diabetes, and gangrene of the lower extremity occurs in $20 \%-30 \%$ of patients with maturity onset diabetes [10]. DFU is basically a pathophysiologic problem in biomechanics of foot. Due to pan neuropathy in diabetes there is altered biomechanics and insensate foot does not appreciate the pressure at planter level and ultimately land up with a diabetic planter ulcer. Offloading is the major solution for healing of this plantar lesions along with adequate blood supply, control of infection, excellent wound care $[11,12]$. The available Offloading techniques are: Bed rest, cutout felt pads, crutches, wheelchairs, zimmer frame, temporary shoes, ortho wedge shoes like rocker-bottom wedge design shoes and total contact casting [13-15]. These devices are expensive. Above all procedures have many advantages towards healing, but disadvantages towards patient compliance \& cost factor. Indian rural population does not allow their wide usage. It does not permit our patient to take complete bed rest. They have to work for their livelihood. The aim of our study is to compare mandakini offloading device [16] suitable for low socio-economic rural population with conventional dressing in the treatment of Diabetic foot plantar ulcer.

\section{Material and Methods}

Interventional study, considering 80 patients with neuropathic diabetic plantar ulcers admitted in R.L. Jalappa hospital and research center Tamaka, Kolar during the period of December 2010 to June 2012.

\section{Definition of study subject}

Any patient with Diabetes Mellitus

\section{Inclusion criteria}

All patients with DM with neuropathic plantar ulcers

\section{Exclusion criteria}

I. Ulcers of Wagener's Grade III, IV and V

II. X-ray showing osteomyelitis

III. Charcot's foot (Photographical)

IV. Ischemic foot $\mathrm{ABPI}<0.4$

V. Patients receiving corticosteroids, immunosuppressive agents, radiation.

The selected patients underwent screening for a period of one to two weeks, to stabilize the wound and institute appropriate medical and surgical line of treatment like diabetic control. Control of infection

*Corresponding author: Vijay P Agrawal, Department of General Surgery, Sri Devraj Urs Medical College, Tamaka, Kolar, Karnataka, India, Tel: +918553363644; E-mail: vijugunnu@gmail.com

Received September 28, 2012; Accepted October 23, 2012; Published November 02, 2012

Citation: Agrawal VP, Sreeramulu PN (2012) Most Easy on the Pocket Offloading Device Costing $<1 \$$ for Rural Diabetic Foot Ulcers. Surgery Curr Res 2:124. doi:10.4172/2161-1076.1000124

Copyright: (c) 2012 Agrawal VP, et al. This is an open-access article distributed under the terms of the Creative Commons Attribution License, which permits unrestricted use, distribution, and reproduction in any medium, provided the original author and source are credited. 
by initiating appropriate antibiotic based on culture sensitivity report, surgical debridement, correction of anemia and correction of other medical illness. After the initial screening period the eligible patients were divided randomly in to test group and control groups.

\section{Test group}

The Mandakini offloading device was applied to the patients (NO MCR CHAPPALS) (Figure 8). Dressing was changed once a week and review was done weekly till 4-6 weeks.

\section{Control group}

The conventional dressing was applied to the patient (WITH MCR CHAPPALS). Dressing was changed as and when required and review was done weekly till 4-6 weeks. The wound response was evaluated weekly using a visual score [17], both in case of Mandakini offloading device and conventional dressing.

The score for the percentage of wound covered by slough and nonviable (necrotic) tissue are-

$1 .=76-100 \%$ wound covered with nonviable tissue.

2. $=51-75 \%$ wound covered with nonviable tissue.

3. $=26-50 \%$ wound covered with nonviable tissue.

4. $=11-25 \%$ wound covered with nonviable tissue.

5. $=0-10 \%$ wound covered with nonviable tissue.

6. $=$ No necrotic tissue.

The score for the percentage of wound covered by granulation tissue are-

1. = No granulation present.

$2 . \leq 25 \%$ of wound covered by granulation tissue.

3. $=25-74 \%$ of wound covered by granulation tissue.

$4 .=75-100 \%$ of wound covered by granulation tissue

The reduction of wound size and area measured in $\mathrm{cm}^{2}$.

The final parameters and wound characteristics of the two randomized groups were analyzed and compared.

- Mandakini offloading device is compared with conventional dressing.

- The selected patient was given a educational material called " 20 Steps Toward Foot Health for People with Diabetes" in their own language [18].

- Treatment of selected patients was done with bed side surgical debridement and a conventional topical antiseptic is applied when required.

\section{Statistical Analysis Used}

Chi Square Test and Fisher Exact Test $[19,20]$

\section{Study design}

An Interventional study, considering 80 patients

\section{Duration of study}

December 2010 to June 2012

\section{Ethical clearance}

Done No.DMC/KLR/MEU/IEC-CER/233

\section{Results}

\section{Age distribution}

Most of the patients fell in the age group between 40 to 70 years. The Mean \pm SD for test group is $(57.85 \pm 13.88)$ and control is $(57.60$ \pm 12.22 ), so age distribution is statistically similar between the two groups with $\mathrm{p}=0.539$ (Table 1, Figure 1).

\section{Sex distribution}

The male and female ratio of the test group is $60 \%: 40 \%$ and the control group is $62.5 \%: 37.5 \%$. Hence Sex distribution is statistically similar between the two groups with $\mathrm{p}=0.818$ (Table 2, Figure 2).

\section{Size of the ulcers}

The mean size of the ulcer was $4.5 \mathrm{~cm}$. The mean \pm SD of the size of ulcer in test group $(4.525 \pm 2.47)$ and in control group $(4.675 \pm 2.43)$

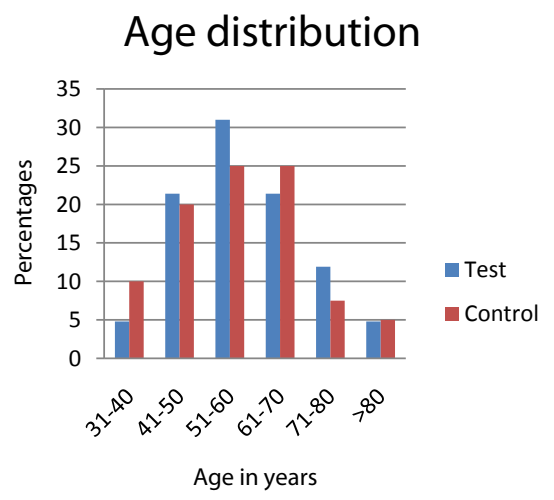

Figure 1: Age distribution in test group and control group.

\begin{tabular}{|c|c|c|c|c|}
\hline \multirow{2}{*}{ Age in years } & \multicolumn{2}{|c|}{ Test group } & \multicolumn{2}{|c|}{ Control group } \\
\hline & No & $\%$ & No & $\%$ \\
\hline $31-40$ & 2 & 4.8 & 4 & 10.0 \\
\hline $41-50$ & 9 & 21.4 & 8 & 20.0 \\
\hline $51-60$ & 13 & 31.0 & 10 & 25.0 \\
\hline $61-70$ & 9 & 21.4 & 10 & 25.0 \\
\hline $71-80$ & 5 & 11.9 & 5 & 7.5 \\
\hline$>80$ & 2 & 4.8 & 3 & 5.0 \\
\hline Total & 40 & 100.0 & 40 & 100.0 \\
\hline Mean \pm SD & \multicolumn{2}{|c|}{$57.85 \pm 13.88$} & \multicolumn{2}{|c|}{$57.6 \pm 12.22$} \\
\hline Inference & \multicolumn{4}{|c|}{$\begin{array}{l}\text { Inference Age distribution is statistically similar between the two } \\
\text { groups with } P=0.539\end{array}$} \\
\hline
\end{tabular}

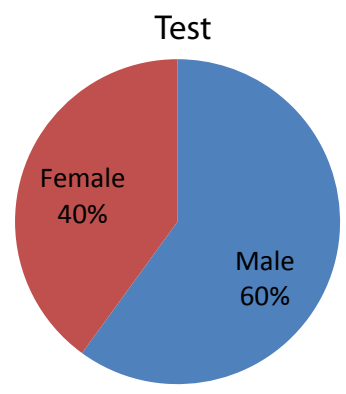

Figure 2: Sex distribution in test group and control group. 


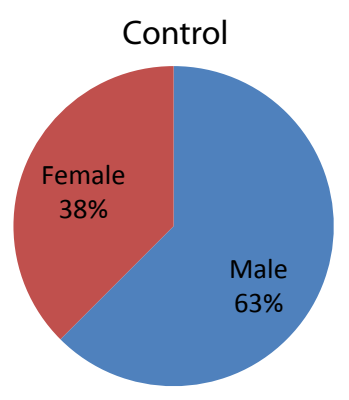

Figure 2a: Sex distribution in test group and control group.

\begin{tabular}{|l|l|l|l|l|}
\hline \multirow{2}{*}{ Sex distribution } & Test group & Test group \\
\cline { 2 - 5 } & No & $\%$ & No & $\%$ \\
\hline Male & 24 & 60.0 & 25 & 62.5 \\
\hline Female & 16 & 40.0 & 15 & 37.5 \\
\hline Total & 40 & 100.0 & 40 & 100.0 \\
\hline Inference & $\begin{array}{l}\text { Sex distribution is statistically similar between the two groups } \\
\text { with } \mathbf{P = 0 . 8 1 8}\end{array}$ \\
\hline
\end{tabular}

Table 2: Sex distribution in test group and control group.

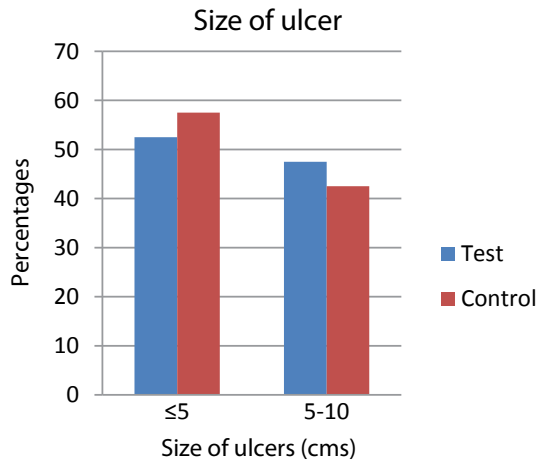

Figure 3: Size of the Ulcers in test group and control group.

is statistically similar between the two groups with $\mathrm{p}=0.785$ (Table 3 , Figure 3).

\section{Grade of ulcers}

Most of the patients had Grade I and II ulcers in both test and control groups. The grade of ulcer is statistically similar between the two groups $\mathrm{p}=0.648$ (Table 4, Figure 4).

\section{Presence of necrotic tissue or slough}

Number of patients with No Necrotic tissue are significantly higher in Test group at $3^{\text {rd }}$ week follow up $(\mathrm{p}=0.178)$, at $4^{\text {th }}$ week $(\mathrm{p} \leq 0.001)$, at $5^{\text {th }}$ week $(\mathrm{p} \leq 0.001)$, at $6^{\text {th }}$ week $(\mathrm{p} \leq 0.001)$ when compared to Control group as per the Chi-Square/Fisher Exact test (Table 5, Figures 5a and 5b).

\section{Presence of granulation tissue}

Number of patients with $75-100 \%$ wound filled are significantly higher in Test group at $3^{\text {rd }}$ week follow up $(\mathrm{p}=0.009)$, at $4^{\text {th }}$ week $(\mathrm{p}=0.002)$, at $5^{\text {th }}$ Week $(\mathrm{p}=0.063)$, and at $6^{\text {th }}$ week $(\mathrm{p} \leq 0.001)$ when compared to Control group as per the Chi-Square /Fisher Exact test (Table 6, Figures 6a and 6b).

\section{Wound surface area}

Number of patients with no wound surface (Nil) are significantly higher in Test group at $3^{\text {rd }}$ week follow up $(\mathrm{p}=0.104)$, at $4^{\text {th }}$ week $(\mathrm{p}=0.118)$, at $5^{\text {th }}$ Week $(\mathrm{p} \leq 0.001)$, and at $6^{\text {th }}$ week $(\mathrm{p} \leq 0.001)$ when compared to Control group as per the Chi-Square/Fisher Exact test (Table 7, Figures $7 \mathrm{a}$ and $7 \mathrm{~b}$ ).

\begin{tabular}{|l|l|l|l|l|}
\hline \multirow{2}{*}{$\begin{array}{l}\text { Size of the ulcers } \\
\text { in } \mathrm{cms}\end{array}$} & \multicolumn{2}{|l|}{ Control group $\mathrm{n}=40$} & \multicolumn{2}{l|}{ Test group $\mathrm{n}=40$} \\
\hline & No & $\%$ & No & $\%$ \\
\hline$\leq 5$ & 21 & 52.5 & 23 & 57.5 \\
\hline $5-10$ & 19 & 47.5 & 17 & 42.5 \\
\hline Mean \pm SD & $4.675 \pm 2.43$ & $4.525 \pm 2.47$ \\
\hline Inference & $\begin{array}{l}\text { Size of the ulcers is statistically similar between the two } \\
\text { groups with } \mathbf{P = 0 . 7 8 5}\end{array}$ \\
\hline
\end{tabular}

Table 3: Size of the Ulcers in test group and control group.

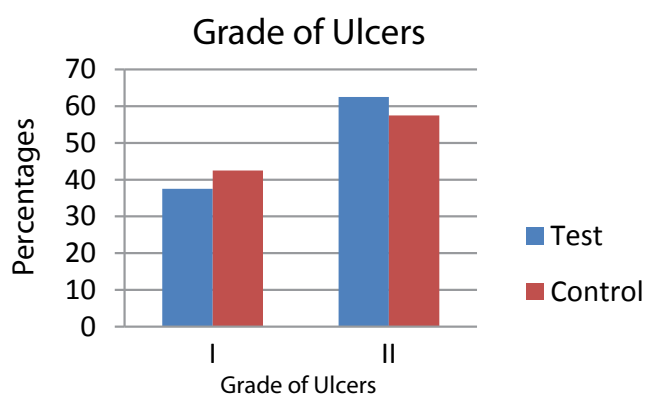

Figure 4: Grade of ulcer in test and control group.

\begin{tabular}{|l|l|l|l|l|}
\hline \multirow{2}{*}{ Grade of Ulcers } & \multicolumn{2}{|l|}{ Control group $\mathrm{n}=40$} & \multicolumn{2}{l|}{ Test group $\mathrm{n}=40$} \\
\cline { 2 - 5 } & No & $\%$ & No & $\%$ \\
\hline I & 15 & 37.5 & 17 & 42.5 \\
\hline II & 25 & 62.5 & 23 & 57.5 \\
\hline
\end{tabular}

Table 4: Grade of Ulcers in test group and control group.

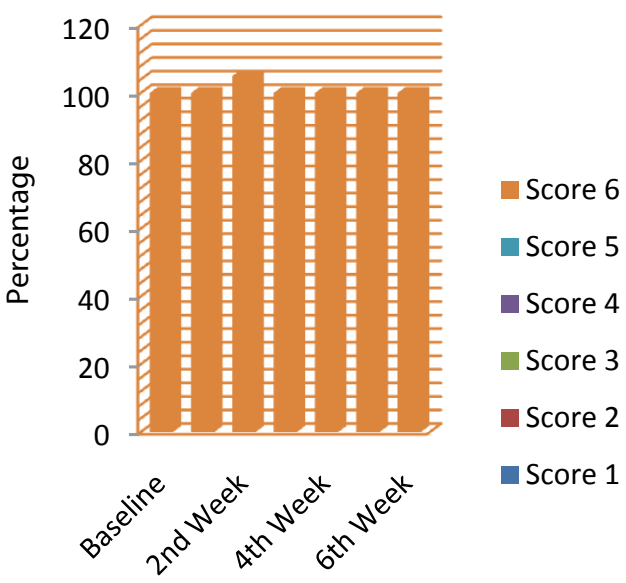

Follow-up

Control Group

Figure 5: The bar chart shows gradual regression of necrotic tissue in test and control groups. 
Citation: Agrawal VP, Sreeramulu PN (2012) Most Easy on the Pocket Offloading Device Costing $<1 \$$ for Rural Diabetic Foot Ulcers. Surgery Curr Res 2:124. doi:10.4172/2161-1076.1000124

Page 4 of 7

\section{Discussion}

The number of patients studied was 80 and randomly divided in to test group (40) and control group (40). Both the test and control groups were matched regarding their age, diabetic status, nutritional status, and grade of ulcer. In addition, there were no significant differences between the two groups with respect to baseline ulcer size $(\mathrm{p}=0.785)$ and amount of nonviable tissue/slough. The Number of patients with no necrotic tissue is significantly higher in Test group at $3^{\text {rd }}$ week follow up ( $\mathrm{p}=0.178)$, at $4^{\text {th }}$ week $(\mathrm{p} \leq 0.001)$, at $5^{\text {th }}$ week $(\mathrm{p} \leq 0.001)$ and at $6^{\text {th }}$ week ( $\mathrm{p} \leq 0.001$ ) when compared to Control group. There is minimal loss of viable tissue in the test group compared to that of control group this is because the number of bed side surgical debridement required is less and done superficially to remove dead tissue only. The number of patients with $75-100 \%$ wound filled by granulation tissue is significantly higher in Test group at $3^{\text {rd }}$ week follow up $(\mathrm{p}=0.009)$, at $4^{\text {th }}$ week $(\mathrm{p}=0.002)$, at $5^{\text {th }}$ Week $(\mathrm{p}=0.063)$, at $6^{\text {th }}$ week $(\mathrm{p} \leq 0.001)$ when compared to Control group.

The number of patients with no wound surface (Nil) is significantly

\begin{tabular}{|c|c|c|c|c|c|c|c|c|c|c|c|c|}
\hline \multirow{2}{*}{$\begin{array}{l}\text { Study } \\
\text { period }\end{array}$} & \multicolumn{6}{|c|}{ Control group Visual score of slough covering the ulcer } & \multicolumn{6}{|c|}{ Test group Visual score of slough covering the ulcer } \\
\hline & 1 & 2 & 3 & 4 & 5 & 6 & 1 & 2 & 3 & 4 & 5 & 6 \\
\hline Baseline & $21(52.5)$ & $12(30)$ & $6(15)$ & $1(2.5)$ & & & $23(57.5)$ & $10(25.0)$ & $7(17.5)$ & & & \\
\hline $1^{\text {st }}$ Week & $15(37.5)$ & $11(27.5)$ & $7(17.5)$ & 7 (17.5) & & & $20(50.0)$ & $9(22.5)$ & $5(12.5)$ & $3(7.5)$ & $3(7.5)$ & \\
\hline $2^{\text {nd }}$ Week & $9(22.5)$ & $10(25)$ & $8(20)$ & $4(10)$ & $11(27.5)$ & & $6(15.0)$ & $17(42.5)$ & 7 (17.5) & 5 (12.5) & 5 (12.5) & \\
\hline $3^{\text {rd }}$ Week & $7(17.5)$ & $13(32.5)$ & 7 (17.5) & $10(25)$ & $3(7.5)$ & & $2(5.0)$ & $12(30.0)$ & $9(22.5)$ & $8(20.0)$ & $9(22.5)$ & \\
\hline $4^{\text {th }}$ Week & $5(12.5)$ & $15(37.5)$ & $6(15)$ & 7 (17.5) & 7 (17.5) & & & $1(2.5)$ & $14(35.0)$ & $8(20.0)$ & $9(22.5)$ & $8(20.0)$ \\
\hline $5^{\text {th }}$ Week & & $9(22.5)$ & $13(32.5)$ & 9 (22.5) & $9(22.5)$ & & & & $6(15.0)$ & 7 (17.5) & 7 (17.5) & $20(50.0)$ \\
\hline $6^{\text {th }}$ Week & & $5(12.5)$ & 15 (37.5) & 7 (17.5) & $5(12.5)$ & $8(20)$ & & & & $3(7.5)$ & 5 (12.5) & $32(80.0)$ \\
\hline
\end{tabular}

Inference Number of patients with No Necrotic tissue are significantly higher in Test group at $3^{\text {rd }}$ week follow up $(P=0.178)$, at $4^{\text {th }}$ week $(P \leq 0.001)$, at $5^{\text {th }}$ Week $(P \leq$ Inference 0.001$)$, at $6^{\text {th }}$ week $(P \leq 0.001)$ when compared to Control group as per the Chi-Square/Fisher Exact test

Figures in brackets are percentages

Visual score:

1. $76-100 \%$ wound covered with nonviable tissue

2. $51-75 \%$ wound covered with nonviable tissue

3. $26-50 \%$ wound covered with nonviable tissue

4. $11-25 \%$ wound covered with nonviable tissue

5. $0-10 \%$ wound covered with nonviable tissue

6. no necrotic tissue

Table 5: Presence of necrotic tissue or slough in test group and control group.

\begin{tabular}{|c|c|c|c|c|c|c|c|c|}
\hline \multirow{2}{*}{$\begin{array}{l}\text { Study } \\
\text { period }\end{array}$} & \multicolumn{4}{|c|}{$\begin{array}{l}\text { Control group } \\
\text { Visual score of granulation tissue covering the ulcer }\end{array}$} & \multicolumn{4}{|c|}{$\begin{array}{l}\text { Test group } \\
\text { Visual score of granulation tissue covering the ulcer }\end{array}$} \\
\hline & 1 & 2 & 3 & 4 & 1 & 2 & 3 & 4 \\
\hline Baseline & $23(57.5)$ & $13(32.5)$ & $4(10.0)$ & & $23(57.5)$ & $13(32.5)$ & $4(10.0)$ & \\
\hline $1^{\text {st }}$ Week & $23(57.5)$ & 9 (22.5) & $8(20.0)$ & & $23(57.5)$ & 9 (22.5) & $8(20.0)$ & \\
\hline $2^{\text {nd }}$ Week & $17(42.5)$ & $16(40.0)$ & $6(15.0)$ & $1(2.5)$ & $9(22.5)$ & $18(45.0)$ & $10(25.0)$ & $3(7.5)$ \\
\hline $3^{\text {rd }}$ Week & $12(30.0)$ & $14(35.0)$ & $10(25.0)$ & $4(10.0)$ & $1(2.5)$ & $22(55.0)$ & $11(27.5)$ & $6(15.0)$ \\
\hline $4^{\text {th }}$ Week & $12(30.0)$ & $12(30.0)$ & $10(25.0)$ & $6(15.0)$ & & $14(35.0)$ & $18(45.0)$ & $8(20.0)$ \\
\hline $5^{\text {th }}$ Week & & $14(35.0)$ & $16(40.0)$ & $10(25.0)$ & & $8(20.0)$ & $12(30.0)$ & $20(50.0)$ \\
\hline $6^{\text {th }}$ Week & & $12(30.0)$ & $20(50.0)$ & $8(20.0)$ & & & $8(20.0)$ & $32(80.0)$ \\
\hline
\end{tabular}

Number of patients with $75-100 \%$ wound filled are significantly higher in Test group at $3^{\text {rd }}$ week follow up $(P=0.009)$, at $4^{\text {th }}$ week $(P=0.002)$, at $5^{\text {th }}$ Week

Inference $\quad(P=0.063)$, and at $6^{\text {th }}$ week $(P \leq 0.001)$ when compared to Control group as per the Chi-Square/Fisher Exact test

Figures in brackets are percentage

Visual score:

1. = no granulation present

2. $\leq 25 \%$ of wound

3. $=25-74 \%$ of wound filled

$4 .=75-100 \%$ of wound filled

Table 6: Presence of granulation tissue in test group and control group.

\begin{tabular}{|c|c|c|c|c|c|c|}
\hline \multirow{3}{*}{$\begin{array}{l}\text { Study } \\
\text { period }\end{array}$} & \multicolumn{3}{|c|}{ Control group } & \multicolumn{3}{|l|}{ Test group } \\
\hline & \multicolumn{6}{|c|}{ Wound Surface area $(\mathrm{cm} 2)$} \\
\hline & $5-10$ & $1-5$ & Nil & $5-10$ & $1-5$ & Nil \\
\hline Baseline & $30(75.0)$ & $10(25.0)$ & & $31(77.5)$ & $9(22.5)$ & \\
\hline $1^{\text {st }}$ Week & $30(75.0)$ & $10(25.0)$ & & $30(75.0)$ & $10(25.0)$ & \\
\hline $2^{\text {nd }}$ Week & $30(75.0)$ & $10(25.0)$ & & $25(62.5)$ & $15(37.5)$ & \\
\hline $3^{\text {rd }}$ Week & $28(70.0)$ & $12(30)$ & & $20(50.0)$ & $18(45.0)$ & $2(2.5)$ \\
\hline $4^{\text {th }}$ Week & $22(55.0)$ & $16(40.0)$ & $2(2.5)$ & $17(42.5)$ & $15(37.5)$ & $8(20.0)$ \\
\hline $5^{\text {th }}$ Week & $16(40.0)$ & $18(45.0)$ & $6(15.0)$ & $2(2.5)$ & $18(45.0)$ & $20(50.0)$ \\
\hline $6^{\text {th }}$ Week & $2(2.5)$ & $28(70.0)$ & $10(25.0)$ & $2(2.5)$ & $6(15.0)$ & $32(80.0)$ \\
\hline Inference & \multicolumn{6}{|c|}{$\begin{array}{l}\text { Number of patients with No Wound surface }(\mathrm{Nil}) \text { are significantly higher in Test group at } 3^{\text {rd }} \text { week follow up }(P=0.104) \text {, at } 4^{\text {th }} \text { week }(P=0.118) \text {, at } 5^{\text {th }} \text { Week }(P \\
\leq 0.001) \text {, and at } 6^{\text {th }} \text { week }(P \leq 0.001) \text { when compared to Control group as per the Chi-Square /Fisher Exact test }\end{array}$} \\
\hline
\end{tabular}

Table 7: Wound Surface Area in test group and control group. 


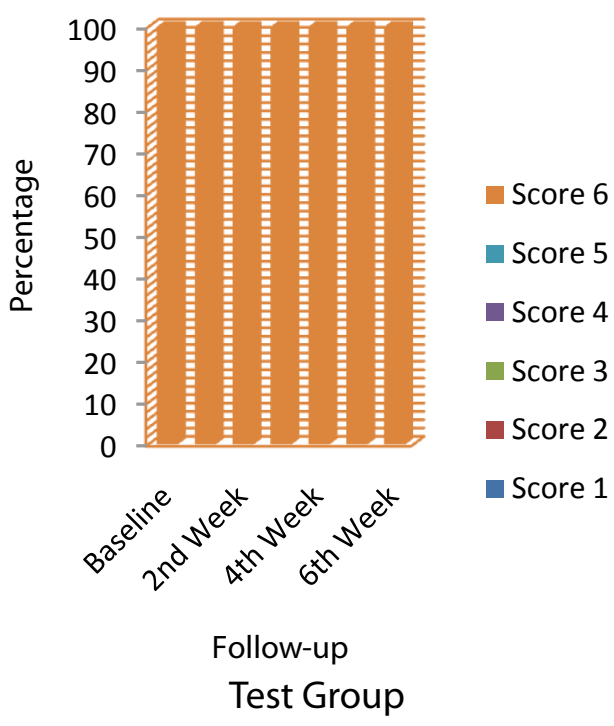

Figure 5a: The bar chart shows gradual regression of necrotic tissue in test and control groups.

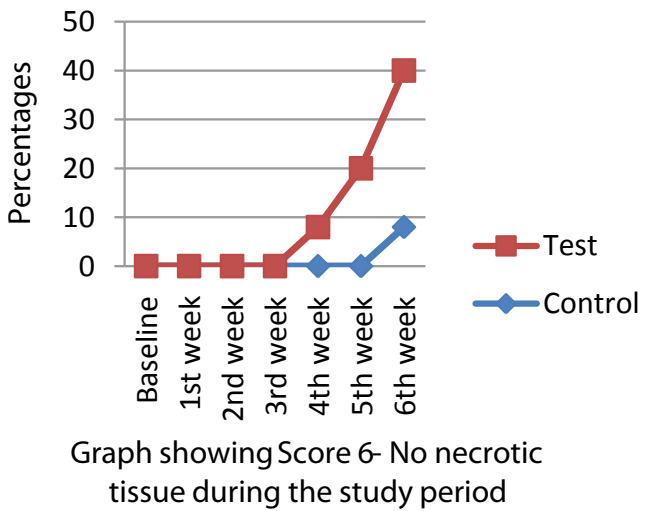

Figure 5b: A comparative line diagram showing presence of necrotic tissue or slough in control and test group in each week.

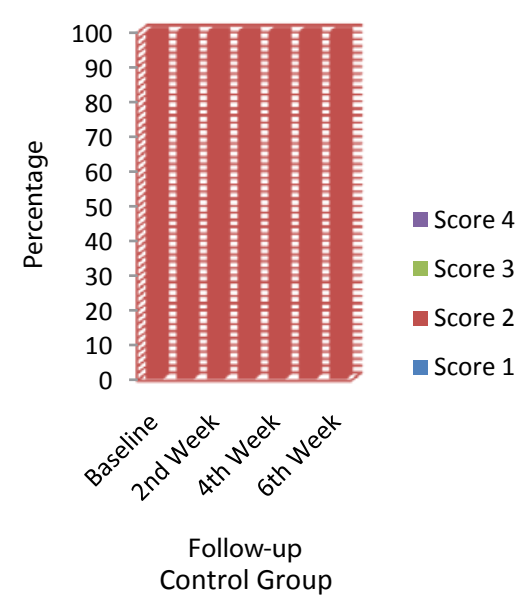

Figure 6: The bar graph shows the gradual progress of granulation tissue in control and test groups in each week.

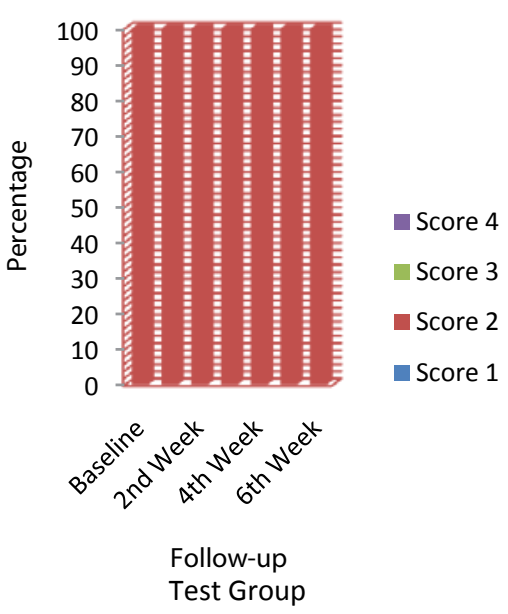

Figure 6a: The bar graph shows the gradual progress of granulation tissue in control and test groups in each week.

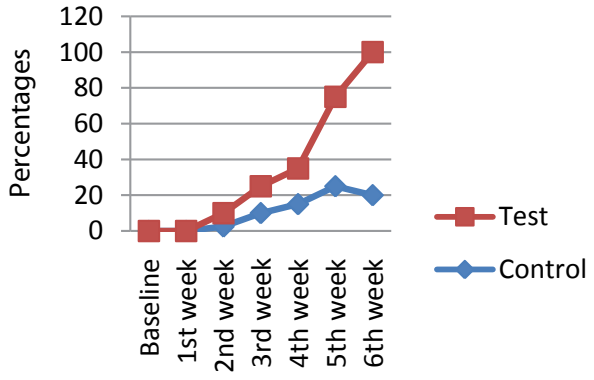

Graph showing Score 4- 75-100\% wound filled during the study

Figure $6 \mathbf{b}$ : Line diagram showing comparative study of gradual progress of granulation tissue in control and test groups in each week.

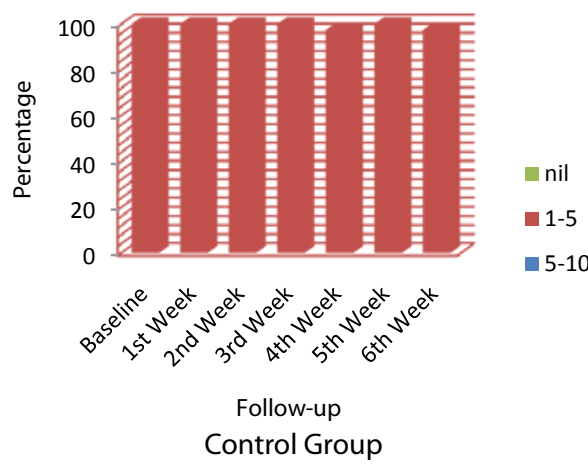

Figure 7: The bar diagram showing shrinking of wound surface in control and test groups in each week.

higher in Test group at $3^{\text {rd }}$ week follow up $(\mathrm{p}=0.104)$, at $4^{\text {th }}$ week $(\mathrm{p}=0.118)$, at $5^{\text {th }}$ week $(\mathrm{p} \leq 0.001)$ and at $6^{\text {th }}$ week $(\mathrm{p} \leq 0.001)$ when compared to Control group. In test group, ulcers healed in 32 patients during follow up for 6 weeks. Among these, 2 patients in 3 weeks, 6 patients in 4 weeks, 12 patients in 5 weeks and 12 patients in 6 weeks. In 8 patients ulcer was not healed but, size of the ulcer decreased during the follow up period. No patients among the test group has secondary 
infection 40 patients were applied conventional dressing. Among these, ulcer healed in 10 patients during follow up for 6 weeks. Among these, 2 patients in 4 weeks, 4 patients in 5 weeks and 4 patients in 6 weeks In 30 patients ulcer was not healed but, size of the ulcer decreased during the follow up period. This study demonstrated that Offloading along with bed side surgical debridement had cumulative effect in reduction of slough, increase granulation tissue and faster wound bed preparation (Figures $8 \mathrm{a}$ and $8 \mathrm{~b}$ ). The test group patients had increased growth of the granulation tissue along with epithelisation which is generally correlated with the development of a granulating wound bed. All this are done with visual score so it cannot be determined whether there was an increase in granulation tissue production resulting from the treatment or that more granulation was visible after debridement. But patients in test group produced better results than the control group. The ulcer also healed faster and has less recurrence rate due to offloading. The study was done to give an insight to the depth of

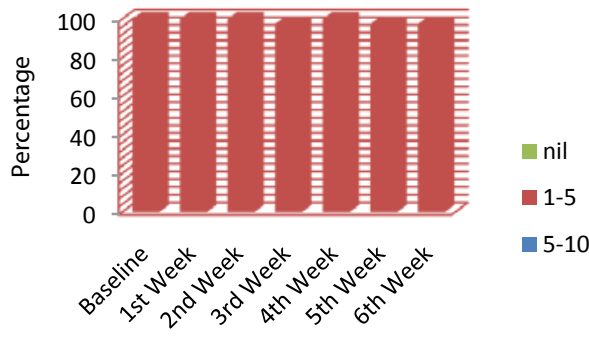

Follow-up

Test Group

Figure 7a: The bar diagram showing shrinking of wound surface in control and test groups in each week.

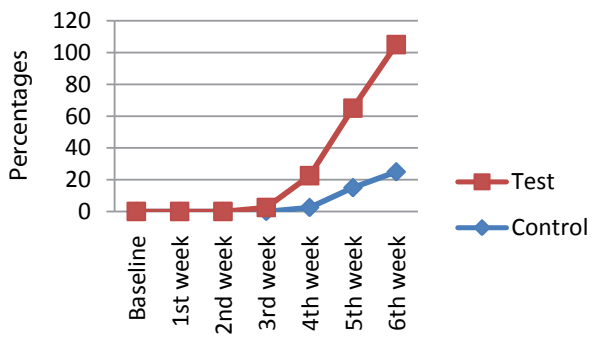

Graph showing ulcers Heeled during the study

Figure $\mathbf{7 b}$ : The comparative line diagram showing shrinking of wound surface in control and test groups in each week.
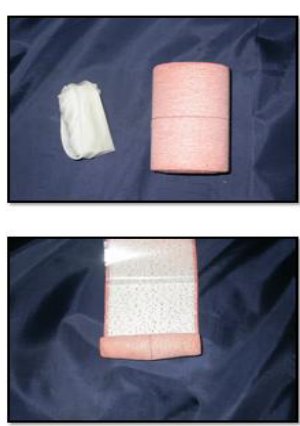

Figure 8: Method to prepare mandakini offloading device [7]
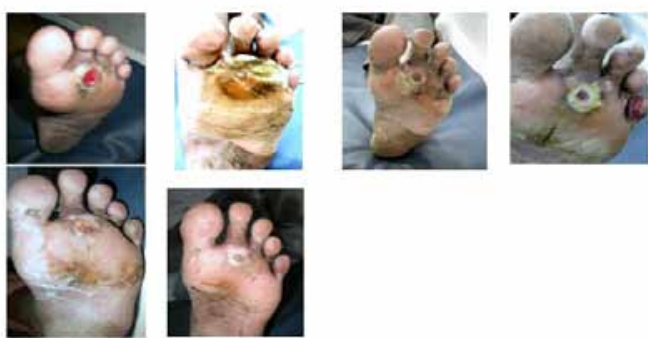

Figure 8a: Healed ulcer after using offloading during weekly follow up.
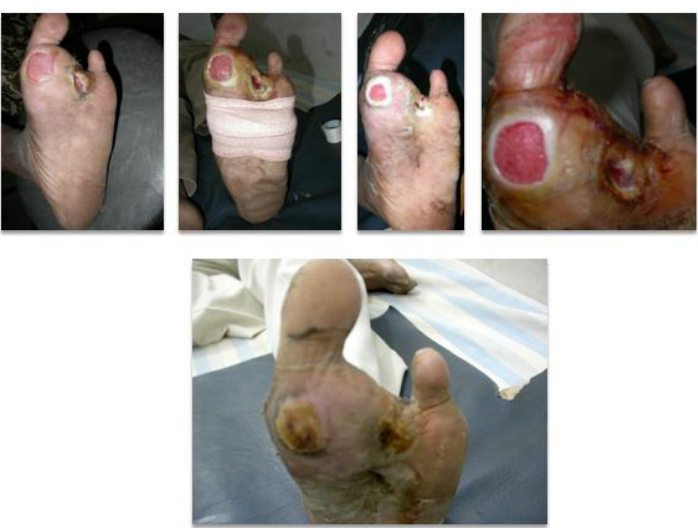

Figure 8b: Healed ulcer after using offloading during weekly follow up.

diabetic wound management, as it has become a foremost problem in recent era. Offloading is one of the cornerstones of gold-standard treatment in diabetic neuropathic foot ulcer.

The study shows the fine efficacy of mandakini offloading device in terms of duration of healing of ulcer, no infection and no recurrence. It is economical, effective and easy to apply. It is ideal offloading device for low socio-economic rural population in developing countries. It reduces the duration of healing of ulcer when compared to conventional dressing. It completes the criteria to be called as ideal offloading device.

\section{Acknowledgement}

Thanks to Dr. Sunil V Kari, Consultant Mandakini hospital, Hubli and Dr. Deepti, Assistant Professor, Department of Community medicine, SDUMC, Kolar for the support.

\section{References}

1. International diabetes federation (2011) The global burden.

2. King H, Aubert RE, Herman WH (1998) Global burden of diabetes, 1995-2025 Prevalence, numerical estimates, and projections. Diabetes Care 21: 14141431.

3. International Diabetes Federation, International Working Group of the Diabetic Foot (2005) Time to act.

4. Lipsky BA (2004) A report from the international consensus on diagnosing and treating the infected diabetic foot. Diabetes Metab Res 20: S68-S77.

5. Jeffcoate WJ, Harding KG (2003) Diabetic foot ulcers. Lancet 361: 1545-1551.

6. Tennvall GR, Apelqvist J, Eneroth M (2000) Costs of deep foot infections in patients with diabetes mellitus. Pharmacoeconomics 18: 225-238.

7. Ramsey SD, Newton K, Blough D, McCulloch DK, Sandhu N, et al. (1999) Incidence, outcomes, and cost of foot ulcers in patients with diabetes. Diabetes Care 22: 382-387. 
8. Most RS, Sinnock P (1983) The epidemiology of lower limb extremity amputations in diabetic individuals. Diabetes Care 6: 87-91.

9. Reiber GE (1996) The epidemiology of diabetic foot problems. Diabet Med 13: S6-S11.

10. Trautner C, Haastert B, Giani G, Berger M (1996) Incidence of lower limb amputations and diabetes. Diabetes Care 19: 1006-1009.

11. Brand PW (1983) The diabetic foot. In: Diabetes mellitus, theory and practice. Ellenberg M, Rifkin H, (Eds), 3rd edition New York: Medical Examination Publishing pp 803-828

12. Frykberg RG, Bailey LF, Matz A Panthel LA, Ruesch G (2002) Offloading properties of a rocker insole. A preliminary study. JAPMA 92: 48-52.

13. American Diabetes Association (1999) Consensus development conference on diabetic foot wound care: 7-8 April 1999, Boston, Massachusetts. American Diabetes Association. Diabetes Care 22: 1354-1360.
14. Pinzur MS, Dart HC (2001) Pedorthic management of the diabetic foot. Foot Ankle Clin 6: 205-214.

15. Armstrong DG, Liswood PL, Todd WF (1995) Potential risks of accommodative padding in the treatment of neuropathic ulcerations. Ostomy Wound Manage 41: 44-49.

16. Sunil V Kari (2010) The economical way to off-load diabetic foot ulcers [Mandakini off-loading device]. Indian J Surg 72: 133-134.

17. Alvarez OM, Fernandez-Obregon A, Rogers RS, Bergamo L, Masso J, et al. (2000) Chemical debridement of pressure ulcers: a prospective, randomized comparative trial of collagenase and papain/urea formulations. Wounds 12: 1525.

18. David G. Armstrong. Southern Arizona Limb Salvage Alliance (SALSA).

19. Bernard Rosner (2000) Fundamentals of Biostatistics, (5thEdn), Duxbury.

20. M. Venkataswamy Reddy (2002) Statistics for Mental Health Care Research NIMHANS publication, India. 